\title{
STABILITAS FISIK SEDIAAN KRIM EKSTRAK ETANOL KULIT BATANG BANYURU (Pterospermum celebiqum Miq.) DENGAN VARIASI PHYTOCREAM ${ }^{\circledR}$
}

\author{
Asnah Marzuki*, Ermina Pakki \\ Laboratorium Kimia Farmasi, Universitas Hasanuddin, Jl. Perintis Kemerdekaan \\ Km 10, Makassar, Sulawesi Selatan \\ *email :asnah_marzuki@yahoo.com
}

\begin{abstract}
ABSTRAK
Telah dilakukan penelitian Stabilitas Fisik Sediaan Krim Ekstrak Etanol Kulit Batang Banyuru (Pterospermum Celebiqum Miq.) Dengan Variasi Phytocream ${ }^{\circledR}$ Penelitian ini mengenai pengaruh emulgator phytocream ${ }^{\circledR}$ terhadap kestabilan fisik sediaan krim dari ekstrak etanol kulit batang banyuru (Pterospermum celebiqum Miq.). Dengan tujuan penelitian, untuk mendapatkan suatu sediaan dengan formula krim yang stabil, menggunakan emulgator phytocream ${ }^{\circledR}$ tipe M/A dari ekstrak etanol kulit batang banyuru. Ekstrak etanol kulit batang banyuru diperoleh dari hasil maserasi dengan etanol 96\%. Di rotavaporasi dan liofilisasi untuk mendapatkan ekstrak kering. Ekstrak etanol kulit batang banyuru diformulasi dalam sediaan krim dalam variasi konsentrasi emulgator phytocream ${ }^{\circledR} 5$, 7, dan $9 \%$. Evaluasi kestabilan fisik krim meliputi uji organoleptis, kriming, viskositas, $\mathrm{pH}$ dan pengukuran tetes terdispersi serta inversi fase sebelum dan setelah kondisi penyimpanan dipercepat selama 12 jam pada suhu $5^{\circ} \mathrm{C}$ dan $35^{\circ} \mathrm{C}$. Pengamatan menunjukkan tidak ada perubahan secara organoleptis, warna dan bau pada tiga formula krim. Data penelitian menunjukkan secara signifikan tidak terjadi adanya kriming, inversi fase, perubahan viskositas, $\mathrm{pH}$, dan ukuran fase terdispersi. Hasil penelitian pada tiga formula krim tipe $\mathrm{M} / \mathrm{A}$ dengan variasi konsentrasi emulgator phytocream ${ }^{\circledR}$ adalah stabil secara fisik.
\end{abstract}

Kata Kunci : phytocream ${ }^{\circledR}$, krim, formula, kulit batang banyuru, uji stabilitas Fisik

\section{ABSTRACT}

The research done of Physical stability cream formulas of ethanol extract from Banyuru stem bark (Pterospermum celebiqum, Miq.) with Phytocream® variations. This research aims to know the effect of phytocream ${ }^{\circledR}$ emulsifier towards to the physical stability cream formulas of extract ethanol from banyuru stem bark (pterospermum celebiqum, Miq.). With the purpose of research, obtaining a stable cream formula, using phytocream ${ }^{\circledR}$ type $M / A$ emulsifier from ethanol extract of 
the banyuru stem bark. Ethanol extract from banyuru stem bark is obtained by maceration with 96 percent ethanol. By rotavaporation and lyophilized, we obtain a dry extract. Ethanol extract of Banyuru stem bark cream formulas formulated in a variety concentration of phytocream ${ }^{\circledR}$ emulsifier are 5, 7, and 9 percent. Evaluation of the physical stability cream formulas include organoleptic test, creamed test, viscosity, $\mathrm{pH}$ and drops dispersed measurement and inversion phase before and after accelerated storage conditions for 12 hours at $5{ }^{\circ}$ Celcius and 35 ${ }^{\circ}$ Celcius. Observations showed that no differently changes in organoleptic, color and odor in three cream formulas. The research data showed that insignificantly effect happen at any creamed, inversion phase, changes in viscosity, $p H$, and dispersed phase sizing. The result of the three types of cream formula $M / A$ is physically stable with various concentrations of phytocream ${ }^{\circledR}$ emulsifier.

Keywords: formula bark banyuru, phytocream $₫$ cream, physical stability test, and concentration varietes

\section{PENDAHULUAN}

Banyuru (Pterosperum celebicum Miq.) merupakan pohon yang berukuran sedang hingga besar hingga lingkar batang 1 meter, tingginya 10-15 m dan berdiameter hingga 100-200 cm (1). Tumbuhan banyuru (Pterosperum celebicum Miq.) secara luas telah dimanfaatkan sebagai obat tradisional oleh masyarakat, yang berkhasiat sebagai obat gatal dan luka pada kulit (2).

Marzuki A. Dkk., (2015) telah melakukan uji aktivitas daya hambat ekstrak etanol kulit batang banyuru (Pterosperum celebicum Miq.) yang menunjukkan bahwa ekstrak dapat menghambat pertumbuhan bakteri Staphylococcus aureus dengan pengukuran daerah hambatan adalah 10,48 $\mathrm{mm}$.

Tumbuhan banyuru mengandung senyawa fenol, flavanoid, tanin dan terpen (4). Emulgator alam komersial yang biasa digunakan dalam formulasi sediaan krim adalah Phytocream ${ }^{\circledR}$, yang merupakan kombinasi antara lipoprotein nabati dan lipid yang berfungsi sebagai surfaktan. Phytocream ${ }^{\circledR}$ merupakan pengemulsi nonionik tipe minyak dalam air (M/A) pada konsentrasi 5-10\% (5).

Krim adalah bentuk formula setengah padat yang mengandung satu atau lebih bahan obat terlarut atau terdispersi dalam bahan dasar yang sesuai. Istilah ini secara tradisional telah digunakan untuk formula setangah padat yang mempunyai konsistensi relatif cair diformulasi sebagai emulsi air dalam minyak atau minyak 
dalam air. Sekarang ini batasan tersebut lebih diarahkan untuk produk yang terdiri dari emulsi minyak dalam air atau dispersi mikrokristal asam-asam lemak atau alkohol berantai panjang dalam air, yang dapat dicuci dengan air dan lebih ditunjukkan untuk penggunaan kosmetik dan estetik (6).

Krim M/A merupakan krim yang bagus untuk sistem penghantaran obat, meneyangkan dalam penampilannya dan rasa yang nyaman setelah penggunaaan. Krim ini tidak berminyak dan bersifat dapat dicuci dengan air baik untuk tujuan topikal, menyebar lebih cepat dan area fase air menguap dari kulit sehingga menyejukkan jaringan yang terinflamasi $(7,8)$.

Efek normal penyimpanan suatu emulsi pada suhu yang lebih tinggi adalah mempercepat koalesensi atau terjadinya krimming dan hal ini biasanya diikuti dengan perubahan viskositas. Kebanyakan emulsi menjadi lebih encer pada suhu tinggi dan menjadi lebih kental bila dibiarkan mencapai suhu kamar. Pembekuan dapat merusak emulsi daripada pemanasan, karena kelarutan emulgator baik dalam fase air maupun fase minyak, lebih senditif pada pembekuan daripada pada pemanasan. Sebelum penyimpanan, kestabilan emulsi dipengaruhi oleh suhu dan waktu. Bentuk ketidakstabilan emulsi selama penyimpanan ditunjukkan dengan terjadinya krimming, perubahan viskositas, perubahan ukuran tetes terdipersi serta inversi fase (9).

Efek normal penyimpanan suatu emulsi pada suhu yang lebih tinggi adalah mempercepat koalesensi atau terjadinya krimming dan hal ini biasanya diikuti dengan perubahan viskositas. Kebanyakan emulsi menjadi lebih encer pada suhu tinggi dan menjadi lebih kental bila dibiarkan mencapai suhu kamar. Pembekuan dapat merusak emulsi daripada pemanasan, karena kelarutan emulgator baik dalam fase air maupun fase minyak, lebih senditif pada pembekuan daripada pada pemanasan (9).

Sebelum penyimpanan, kestabilan emulsi dipengaruhi oleh suhu dan waktu. Bentuk ketidakstabilan emulsi selama penyimpanan ditunjukkan dengan terjadinya krimming, perubahan viskositas, perubahan ukuran tetes terdipersi serta inversi fase (9). Phytocream ${ }^{\circledR}$ mengandung potasium palmitoyl hidrilized wheat protein $50 \%$, glyseryl stearat $25 \%$, cetearyl alcohol $25 \%$. Phytocream ${ }^{\circledR}$ merupakan kombinasi 
antara lipoprotein nabati dan lipid yang berfungsi sebagai surfaktan. Komposisi Phytocream ${ }^{\circledR}$ terdiri dari natrium palmitol yang dihidrolisis dengan protein gandum, gliseril stearat, stetosteril alkohol. Komponen alami dari bahan alam yang tidak mengandung ethylene oxide yang mudah diformulasikan dan mudah ditangani dan digunakan khusus untuk bahan kosmetik. Emulsifikasi dari wheat protein didalam Phytocream ${ }^{\circledR}$ ini sangat stabil dan sesuai untuk penggunaan krim dan lotio, digunakan konsentrasi 5-8 \% sebagai emulgator dan sangat cocok dengan bahan lain juga dapat dikatakan polimer (potasium palmitoyl hidrolized wheat protein). Bentuknya seperti butiran lilin, beraroma khas, berwarna putih gading, mempunyai $\mathrm{pH}$ antara 6,5 - 7,5 dan titik didihnya sekitar $52^{\circ}-60^{\circ} \mathrm{C}(10)$.

\section{METODE}

\section{Alat dan Bahan}

Alat-alat yang digunakan adalah cawan porselen, gelas piala $\left(\right.$ Pyrex $\left.^{\circledR}\right)$, gelas ukur (Pyrex $\left.{ }^{\circledR}\right)$, labu erlenmeyer $\left(\right.$ Pyrex $\left.^{\circledR}\right)$, mortir dan stamfer, mikroskop(L-301A), penangas air (Memment 0003476 ${ }^{\circledR}$ ), perangkat uji konduktivitas (bola lampu, kabel, sumber arus listrik), pH meter $\left(\right.$ Lutron $\left.^{\circledR}\right)$, termometer, timbangan analitik $\left(\right.$ Sartorius $\left.^{\circledR}\right)$, viskometer (Brookfield $\left.{ }^{\circledR}\right)$, autoklaf (All American $\left.{ }^{\circledR}\right)$, climatic chamber (Climacell Sartorius $\left.{ }^{\circledR}\right)$, freeze dryer (CoolSafeTM), homogenizer (Ultra Turax $®)$, ) pH meter (Sartorius $®)$, rotavapor (Heidolph®).

Bahan-bahan yang digunakan yaitu asam stearat, $\alpha$-tokoferol, ekstrak etanol kulit batang banyuru (Pterosperum celebicum Miq.), emulgator Phytocream $^{\circledR}$, metilen biru, metil paraben, propilen glikol, propil paraben, dan setil alkohol.

\section{Penyiapan Bahan}

Sampel kulit batang banyuru (Pterosperum celebicum Miq.) diambil dari Hutan Lindung Jompi’e Kota Pare-Pare. Sampel kulit batang dipisahkan terlebih dahulu antara kulit batang dan kayu batangnya, selanjutnya kulit batang banyuru di cuci dan dikeringkan dengan cara diangin-anginkan, terlindung dari sinar matahari langsung sampai kering, terakhir diserbukkan dengan mesin penggiling,Sampel yang telah ditimbang sebanyak $500 \mathrm{~g}$, diekstraksi secara maserasi menggunakan 
pelarut etanol 96\% sebanyak 2 liter selama 5 hari dan sesekali diaduk, kemudian disaring dan filtrat yang diperoleh dikumpulkan. Residu dimaserasi kembali dengan pelarut dan volume yang sama selama 3 hari, hal ini dilakukan sebanyak tiga kali. Filtrat yang telah dikumpulkan dikisatkan menggunakan rotavapor, hingga ekstrak menjadi kental kemudian diliofilisasi menggunakan freeze-dryer dan diperoleh ekstrak dalam bentuk serbuk kering.

\section{Formulasi krim}

Diformulasi krim tipe minyak dalam air (M/A) yang mengandung ekstrak etanol kulit batang banyuru (Pterosperum celebicum Miq.) menggunakan emulgator Phytocream ${ }^{\circledR}$ dengan konsentrasi 5, 7, dan 9\%.

Tabel 1. Formula Krim Ekstrak Etanol Kulit Batang Banyuru

\begin{tabular}{|c|c|c|c|c|}
\hline \multirow{2}{*}{ No. } & \multirow{2}{*}{ Nama Bahan } & \multicolumn{3}{|c|}{ Formula Krim $(\% \mathrm{~b} / \mathrm{b})$} \\
\hline & & F1 & F2 & F3 \\
\hline 1. & Ekstrak banyuru & 3 & 3 & 3 \\
\hline 2. & Setil alkohol & 2,5 & 2,5 & 2,5 \\
\hline 3. & Asam stearat & 2 & 2 & 2 \\
\hline 4. & Propilen glikol & 15 & 15 & 15 \\
\hline 5. & Metil paraben & 0,2 & 0,2 & 0,2 \\
\hline 6. & Propil paraben & 0,02 & 0,02 & 0,02 \\
\hline 7. & Phytocream ${ }^{\circledR}$ & 5 & 7 & 9 \\
\hline 8. & $\alpha$-tokoferol & 0,05 & 0,05 & 0,05 \\
\hline 9. & Aquadest & 72,23 & 70,23 & 68,23 \\
\hline
\end{tabular}

\section{Pembuatan Krim}

Bahan-bahan ditimbang sesuai rancangan formula pada tabel 1. Fase minyak dibuat dengan cara melebur setil alkohol, asam stearat, propil paraben, $\alpha$ tokoferol dan Phytocream ${ }^{\circledR}$ Secara berturut-turut dalam cawan porselen di atas penangas air hingga suhu $70^{\circ} \mathrm{C}$ sambil diaduk hingga homogen. Fase air dibuat dengan cara memanaskan air hingga $70^{\circ} \mathrm{C}$ dalam gelas piala,kedalamnya dilarutkan metil parabendan ekstrak banyuru. Selanjutnya fase minyak dituang kedalam fase 
air, diaduk dengan pengaduk elektrik hingga homogen. Basis krim terus diaduk hingga suhu kamar.

\section{Evaluasi Krim}

Tipe krim meliputi :

1. Metode Pengenceran, krim dimasukkan dalam vial, kemudian diencerkan dengan ditambahkan air. Jika emulsi dapat diencerkan maka tipe emulsinya M/A.

2. Metode Dispersi Warna, krim dimasukkan ke dalam gelas piala, kemudian ditetesi beberapa tetes larutan metilen biru. Jika warna biru segera terdipersi keseluruh emulsi maka tipe krim M/A.

3. Metode Konduktivitas, Krim dimasukkan sebanyak 25 gram kedalam gelas piala, kemudian dihubungkan dengan rangkaian arus listrik. Uji ini didasarkan pada prinsip bahwa air menghantarkan arus listrik sedangkan minyak tidak apabila lampu menyala maka tipe krim M/A.

Kondisi Penyimpanan Dipercepat yaitu penyimpanan selama beberapa periode (waktu) dengan siklus dua suhu, yaitu $5^{\circ} \mathrm{C}$ dan $35^{\circ} \mathrm{C}$ dalam 12 jam digunakan selama 10 siklus.

Pengamatan organoleptis dilakukan terhadap formula krim meliputi perubahan warna dan bau sebelum dan setelah penyimpanan dipercepat. Pengukuran viskositas dilakukan setelah sepuluh siklus penyimpanan dengan menggunakan viskometer (Brookfield ${ }^{\circledR}$ ) pada 60 rpm menggunakan spindel nomor 7.

Tabel 2. Hasi Pengamatan Ekstrak Etanol Kulit Batang Banyuru

\begin{tabular}{|c|c|}
\hline Parameter & Hasil \\
\hline Warna & Coklat \\
\hline Bau & Khas kulit batang banyuru \\
\hline
\end{tabular}




\section{Evaluasi Kestabilan Fisik Formula}

Pengamatan krim secara organoleptis menunjukkan bahwa tidak terjadi perubahan warna dan bau terhadap formula krim setelah kondisi penyimpanan dipercepat. Hal ini disebabkan karena dasar krim bersifat inert sehingga tidak terjadi interaksi antara basis dengan ekstrak etanol kulit batang banyuru. Pengamatan homogenitas dilakukan sebelum dan sesudah penyimpanan dipercepat dan diperoleh hasil yang tetap homogen pada masing-masing formula. Tidak terjadi perubahan selama proses penyimpanan karena bahan yang digunakan merupakan bahan yang larut dalam masing-masing fase serta cara pembuatan yang homogen. Hasil pengamatan dapat dilihat pada tabel 3.

Tabel 3. Pengamatan Organoleptis Formula Krim

\begin{tabular}{|l|l|l|l|l|l|l|}
\hline \multirow{2}{*}{ Formula } & \multicolumn{2}{|c|}{ Sebelum Penyimpanan Dipercepat } & \multicolumn{3}{|c|}{ Setelah Penyimpanan Dipercepat } \\
\cline { 2 - 7 } & Warna & Bau & Homogenitas & Warna & Bau & Homogenitas \\
\hline F1 & $\begin{array}{l}\text { Coklat } \\
\text { tua }\end{array}$ & $\begin{array}{l}\text { Tidak } \\
\text { Berbau }\end{array}$ & Homogen & $\begin{array}{l}\text { Coklat } \\
\text { tua }\end{array}$ & $\begin{array}{l}\text { Tidak } \\
\text { Berbau }\end{array}$ & Homogen \\
\hline F2 & $\begin{array}{l}\text { Coklat } \\
\text { tua }\end{array}$ & $\begin{array}{l}\text { Tidak } \\
\text { Berbau }\end{array}$ & Homogen & $\begin{array}{l}\text { Coklat } \\
\text { tua }\end{array}$ & $\begin{array}{l}\text { Tidak } \\
\text { Berbau }\end{array}$ & Homogen \\
\hline F3 & $\begin{array}{l}\text { Coklat } \\
\text { tua }\end{array}$ & $\begin{array}{l}\text { Tidak } \\
\text { Berbau }\end{array}$ & Homogen & $\begin{array}{l}\text { Coklat } \\
\text { tua }\end{array}$ & $\begin{array}{l}\text { Tidak } \\
\text { Berbau }\end{array}$ & Homogen \\
\hline
\end{tabular}

Uji konduktivitas menunjukkan semua tipe krim dapat memijarkan lampu karena fase luar adalah air. Uji ini didasarkan pada prinsip bahwa air menghantarkan arus listrik sedangkan minyak tidak, sehingga dapat disimpulkan tipe emulsi M/A.

Tabel 4. Pengamatan Uji Tipe Emulsi

\begin{tabular}{|c|l|l|l|l|l|l|}
\hline \multirow{2}{*}{$\begin{array}{r}\text { 祍 } \\
\text { 王 }\end{array}$} & \multicolumn{2}{|l|}{ Sebelum penyimpanan dipercepat } & \multicolumn{2}{l|}{ Setelah penyimpanan dipercepat } \\
\cline { 2 - 7 } & $\begin{array}{l}\text { Kondukti } \\
\text { vitas }\end{array}$ & $\begin{array}{l}\text { Pengen } \\
\text { ceran }\end{array}$ & $\begin{array}{l}\text { Dispersi } \\
\text { Warna }\end{array}$ & $\begin{array}{l}\text { Kondikti } \\
\text { vitas }\end{array}$ & $\begin{array}{l}\text { Pengen } \\
\text { ceran }\end{array}$ & $\begin{array}{l}\text { Dispersi } \\
\text { Warna }\end{array}$ \\
\hline F1 & M/A & M/A & M/A & M/A & M/A & M/A \\
\hline F2 & M/A & M/A & M/A & M/A & M/A & M/A \\
\hline F3 & M/A & M/A & M/A & M/A & M/A & M/A \\
\hline
\end{tabular}




\section{Pengukuran pH Formula}

Pengukuran $\mathrm{pH}$ pada formula krim dilakukan sebelum dan setelah penyimpanan dipercepat menggunakan alat $\mathrm{pH}$ meter. Berdasarkan hasil pengukuran $\mathrm{pH}$ formula krim, terlihat bahwa terjadi penurunan $\mathrm{pH}$ setelah penyimpanan pada setiap formula. Hal dikarenakan adanya pengaruh $\mathrm{CO}_{2}$ karena $\mathrm{CO}_{2}$ bereaksi dengan fase air sehingga membentuk asam. Penurunan $\mathrm{pH}$ terbesar pada formula $\mathrm{F} 3$ dengan selisih 1,02 dan peningkatan $\mathrm{pH}$ terkecil pada formula $\mathrm{F} 1$ dengan selisih 0,25 . Untuk melihat perbedaan dari ketiga formula maka dilakukan analisis data secara statistik. Hasil analisis data statistik menunjukkan bahwa tidak terdapat perbedaan yang signifikan antara ketiga formula. Meskipun mengalami penurunan $\mathrm{pH}$, namun perubahan tersebut masih berada pada rentang $\mathrm{pH}$ fisiologis kulit yaitu 4,7-6,8 sehingga ketiga formula tersebut stabil secara fisik. Hasil pengukuran $\mathrm{pH}$ formula krim:

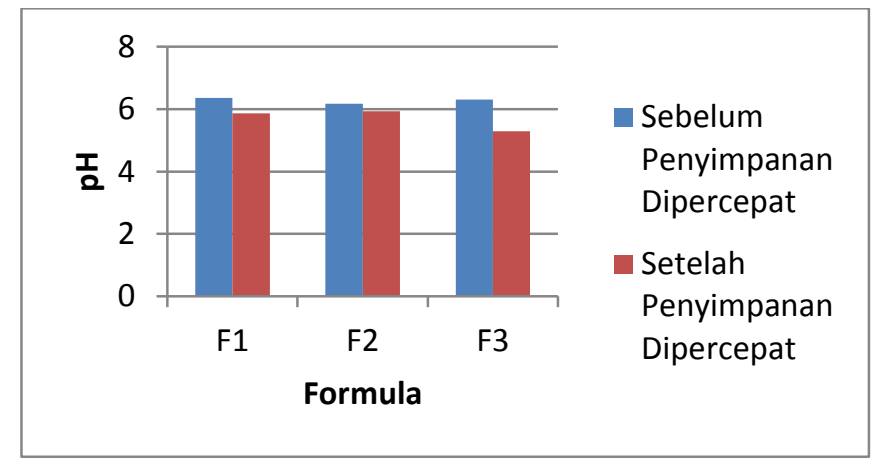

Gambar 1. Histogram pH sebelum dan setelah kondisi penyimpanan dipercepat Pengukuran Ukuran Tetes Terdispersi

Pada pengukuran tetes terdispersi menunjukkan terjadinya perubahan tetes terdispersi pada semua krim. Setelah penyimpanan dipercepat ukuran tetes terdispersi semakin besar. Dari hasil pengukuran ukuran tetes terdispersi terlihat bawha F1 memiliki perubahan paling kecil yaitu sebanyak 61 partikel dan F2 memiliki perubahan paling besar sebanyak 108 partikel. Rata-rata ukuran tetesan terdispersi setiap formula krim ada dalam rentang $0,1-7 \mu \mathrm{m}$, yang menunjukkan bahwa setiap formula krim stabil secara fisik. Rentang ukuran tetes terdispersi suatu 
emulsi adalah 0,1 - $100 \mu \mathrm{m}$, semakin kecil ukuran tetes terdispersi suatu emulsi maka semakin stabil pula emulsi tersebut. Hasil pengukuran tetes terdispersi sebelum dan setelah kondisi penyimpanan dipercepat dapat dilihat pada tabel berikut:

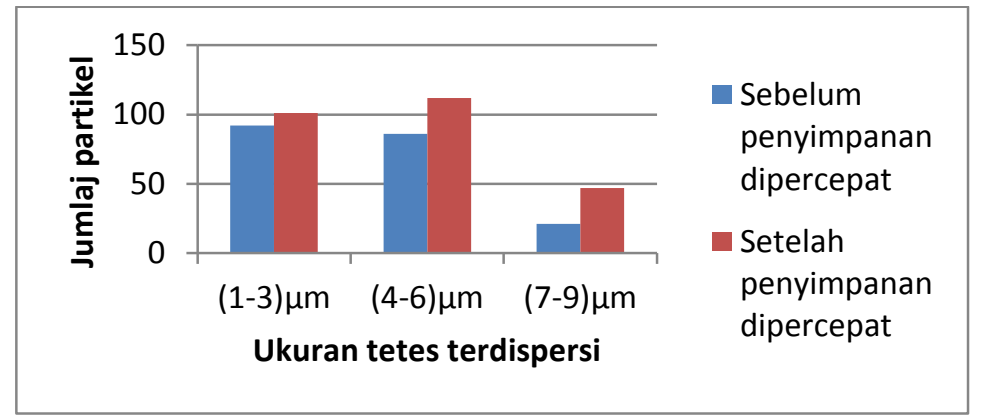

Gambar 2. Histogram ukuran tetesan terdispersi untuk formula Krim F1

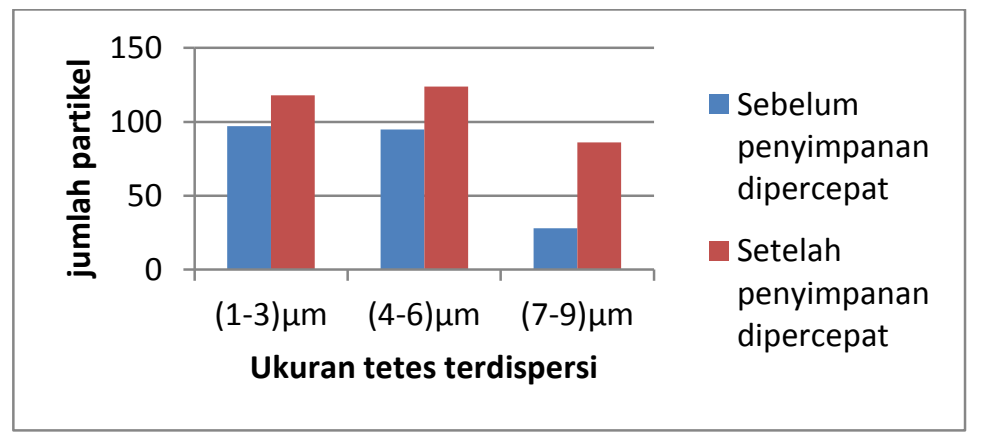

Gambar 3. Histogram ukuran tetesan terdispersi untuk formula Krim F2

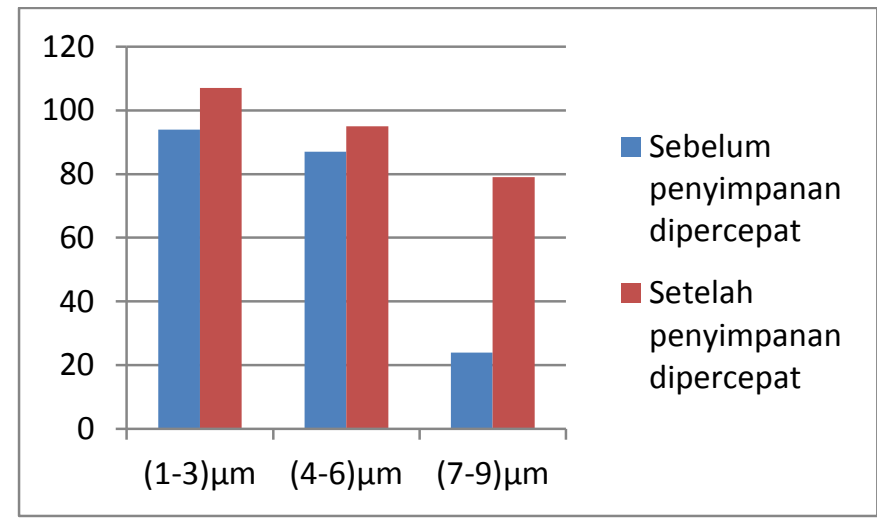

Gambar 4. Histogram ukuran tetesan terdispersi untuk formula Krim F3 


\section{Pengukuran Viskositas Krim}

Pengukuran viskositas pada formula gel dilakukan sebelum dan setelah penyimpanan dipercepat menggunakan alat viskometer dengan spindle no. 7 kecepatan $50 \mathrm{rpm}$. Pengamatan viskositas krim menunjukkan terjadinya kenaikan viskositas pada semua variasi konsentrasi. Hal ini merupakan efek normal penyimpanan suatu emulsi, dimana pada suhu yang lebih tinggi akan mempercepat koalesensi disertai perubahan viskositas. Selain itu, perubahan temperature secara bergantian pada saat proses penyimpanan dipercepat dapat menyebabkan terjadinya penguapan air dari sediian sehingga viskositas krim meningkat. Umumnya krim menjadi lebih encer pada suhu tinggi dan menjadi lebih kental bila dibiarkan mencapai suhu kamar. Dari hasil pengukuran viskositas memperlihatkan dari ketiga formula krim dengan emulgator phytocream ${ }^{\circledR}$ yang memiliki perubahan viskositas paling stabil adalah F1 dan F2.

Hasil pengukuran viskositas sebelum dan setelah kondisi penyimpanan dipercepat dapat dilihat pada gambar 5 .

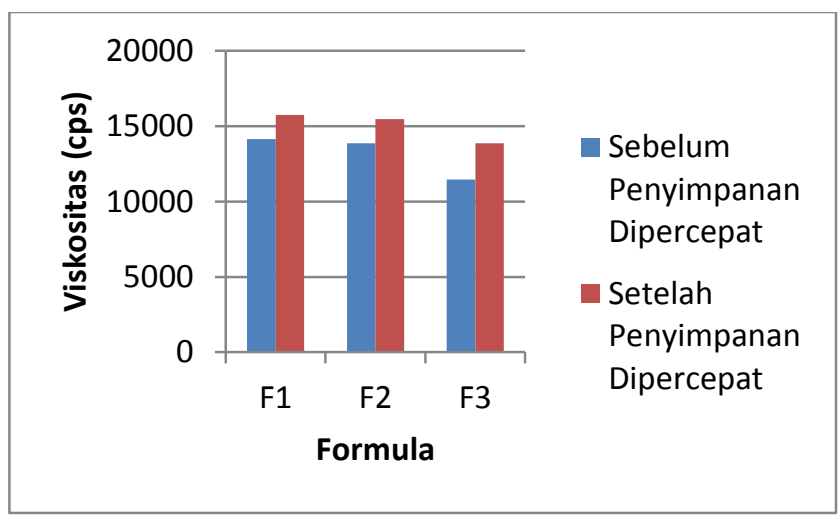

Gambar 5. Histogram viskositas krim (cps) sebelum dan setelah kondisi penyimpanan dipercepat.

Keterangan :

M/A : Emulsi tipe minyak dalam air

F1,F2, F3 : Krim dengan konsentrasi emulgator phytocream 5, 7, 9\%

\section{KESIMPULAN}

Berdasarkan hasil penelitian, dapat disimpulkan :

1. Ekstrak etanol kulit batang banyuru dapat diformulasikan dalam sediaan krim dengan konsentrasi emulgator phytocream ${ }^{\circledR}$ 5, 7 dan $9 \%$ adalah stabil secara 
fisik berdasarkan hasil pengujian organoleptik, kriming, viskositas, $\mathrm{pH}$, inversi fase, serta pengukuran viskositas dan ukuran tetes terdispersi.

2. Formula krim ekstrak etanol kulit batang banyuru yang menunjukkan karakteristik fisik dan kestabilan yang paling baik adalah F1.

\section{SARAN}

Sebaiknya dilakukan penelitian lanjutan berupa uji iritasi dan uji efektivitas formula krim ekstrak etanol kulit batang banyuru terhadap hewan coba berupa kelinci.

\section{DAFTAR PUSTAKA}

Heryati Yetti, Nina Mandawati, dan Kokasih A.S. 2003. Bayur. Departemen Kehutanan. Badan Penelitian dan Pengembangan Kehutanan.

Sossef, M. S., M.,Hong,L.T. and Prawirohatmodjo,S.1998. No 5 (3). Prosea Bogor Indonesia 479-48.

Djuanda A, Hamzah M, Aisah S. Ilmu Penyakit Kulit dan Kelamin. Ed.Kelima. Balai Penerbit FKUI. Jakarta. 2009. hal. 253-254, 258-259.

Lachman L, Herbert AL, Joseph LK. The Theory and Practice of Industry. Third Edit. Lea \& Fegiber. Philadelphia. 1994. Hal, 528, 508, 531, 538.

Gennaro AR. Remington's Pharmaceutical Science. $21^{\text {st }}$ Editon. Mack Publishing Company. Pennsylvania.2005.hal 327 -31 Available as PDF file.

Baumann L. Cosmetic Dermatology Principles and Practice second Edition. The McGraw-Hill Companies. New York. 2009. pp.3 [Available as PDF file].

Marzuki Asnah.et all., 2016. Potential Anti-Infection Activity Of Ethanol Extract Stem Bark Banyuru (Pterospermum Celebicum, Miq.) Against Several acteria.Asian Journal Of Microbiology, Biotechnology And Environmental Sciences, Vol. 18, No. 4

Parrott, E.L., Pharmaceutical Technology. Fundamental Pharmaceutics. [Third Revition]. Burgess Publishing Company. Minneapolis. 1971.hal 313

Allen LV. The Art, Science and Technology of Pharmaceutical Compounding. Washington D.C: American Pharmaceutical Association. 2002.

Sinerga,VegetableBasedEmulsifier[bookoninternet].2008.[accessed07oktober201 6]http:://www.in.cosmetics.com/exhibitorlibrary/g/phytocream.pdf. 